\title{
Sensitive quantification of Clostridium perfringens in human feces by quantitative real-time PCR targeting alpha-toxin and enterotoxin genes
}

Ravinder Nagpal ${ }^{1{ }^{*}+}$, Kiyohito Ogata ${ }^{2 \dagger}$, Hirokazu Tsuji ${ }^{2}$, Kazunori Matsuda ${ }^{3}$, Takuya Takahashi ${ }^{2}$, Koji Nomoto $^{2}$, Yoshio Suzuki ${ }^{4}$, Kazunari Kawashima ${ }^{5}$, Satoru Nagata ${ }^{6}$ and Yuichiro Yamashiro ${ }^{1}$

\begin{abstract}
Background: Clostridium perfringens is a widespread pathogen, but the precise quantification of this subdominant gut microbe remains difficult due to its low fecal count (particularly in asymptomatic subjects) and also due to the presence of abundant polymerase-inhibitory substances in human feces. Also, information on the intestinal carriage of toxigenic C. perfringens strains in healthy subjects is sparse. Therefore, we developed a sensitive quantitative real-time PCR assays for quantification of $C$. perfringens in human feces by targeting its a-toxin and enterotoxin genes. To validate the assays, we finally observed the occurrence of a-toxigenic and enterotoxigenic C. perfringens in the fecal microbiota of healthy Japanese infants and young adults.

Methods: The plc-specific qPCR assay was newly validated, while primers for 165 rRNA and cpe genes were retrieved from literature. The assays were validated for specificity and sensitivity in pre-inoculated fecal samples, and were finally applied to quantify C. perfringens in stool samples from apparently healthy infants (n 124) and young adults (n 221).

Results: The GPCR assays were highly specific and sensitive, with a minimum detection limit of $10^{3}$ bacterial cells/g feces. Alpha-toxigenic C. perfringens was detected in $36 \%$ infants and $33 \%$ adults, with counts ranging widely $\left(10^{3}\right.$ $10^{7}$ bacterial cells/g). Intriguingly, the mean count of a-toxigenic C. perfringens was significantly higher in infants ( $6.0 \pm 1.5 \log _{10}$ bacterial cells/g), as compared to that in adults (4.8 \pm 1.2$)$. Moreover, the prevalence of enterotoxigenic C. perfringens was also found to be significantly higher in infants, as compared to that in adults. The mean enterotoxigenic C. perfringens count was $5.9 \pm 1.9$ and $4.8 \pm 0.8 \log _{10}$ bacterial cells/g in infants and adults, respectively.
\end{abstract}

Conclusions: These data indicate that some healthy infants and young adults carry a-toxigenic and enterotoxigenic C. perfringens at significant levels, and may be predisposed to related diseases. Thus, high fecal carriage of toxigenic C. perfringens in healthy children warrants further investigation on its potential sources and clinical significance in these subjects. In summary, we present a novel qPCR assay for sensitive and accurate quantification of a-toxigenic and enterotoxigenic C. perfringens in human feces, which should facilitate prospective studies of the gut microbiota.

Keywords: Alpha-toxin, Clostridium perfringens, Enterotoxin, Intestinal microbiota, Gut pathogens, Phospholipase C, Quantitative PCR

\footnotetext{
* Correspondence: ravinder@juntendo.ac.jp

†Equal contributors

'Probiotics Research Laboratory, Juntendo University Graduate School of

Medicine, Tokyo, Japan

Full list of author information is available at the end of the article
}

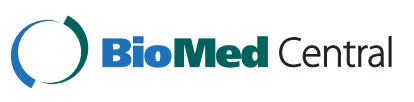

(c) 2015 Nagpal et al. Open Access This article is distributed under the terms of the Creative Commons Attribution 4.0 International License (http://creativecommons.org/licenses/by/4.0/), which permits unrestricted use, distribution, and reproduction in any medium, provided you give appropriate credit to the original author(s) and the source, provide a link to the Creative Commons license, and indicate if changes were made. The Creative Commons Public Domain Dedication waiver (http://creativecommons.org/publicdomain/zero/1.0/) applies to the data made available in this article, unless otherwise stated. 


\section{Background}

Clostridium perfringens is one of the most widely dispersed opportunistic pathogens [1] and is well known to produce a number of toxins to cause several forms of histotoxic and enteric diseases in humans and animals [2]. Based on the production of four major toxins i.e., alpha, beta, epsilon and iota, it is categorized into five toxin-types viz. A, B, C, D and E [3]. While it is ambiguous why $C$. perfringens produces so many diverse toxins, it is well known that it uses chromosomally-encoded $\alpha$ toxin (which has phospholipase $\mathrm{C}(p l c)$ and sphingomyelinase activities with hemolytic, necrotic and lethal abilities) as a chief virulent factor and key mediator for most of C. perfringens-associated diseases [4]. Alpha-toxin is produced by all $C$. perfringens toxin-types but type A produces higher amounts than the other types [1]. In addition, few $C$. perfringens strains also harbor cpe (C. perfringens enterotoxin, a clinically important enterotoxin) gene which is responsible for most of the C. perfringens food-poisoning outbreaks and diarrheal cases [5]. Under favorable conditions, the organism can cause gas gangrene, food-poisoning and gastrointestinal illnesses including antibiotic-associated diarrhea, sporadic diarrhea, and nosocomial diarrheal diseases in humans [6-9]. However, in spite of their ubiquitous environmental distribution and implication in various food-poisoning outbreaks worldwide [10, 11], very little information is available on the relative occurrence of $\alpha$-toxigenic and enterotoxigenic strains of C. perfringens in general populations, particularly in Japan where $C$. perfringens food poisoning has been ranked as third or fourth most common food poisoning [12-14].

Generally, a high $C$. perfringens count $\left(>10^{6} \mathrm{cfu} / \mathrm{g}\right.$ feces) is considered as an indicator of $C$. perfringens food-poisoning [15-18]. C. perfringens in fecal samples has traditionally been detected by conventional microbiological culture methods, biochemical analyses, tissue culture cytotoxicity assays, mouse bioassays or immunosorbent assays [19-21], but these methods are laborious and time-consuming. Culture of $C$. perfringens is not recommended for diagnosis, mainly because of relative ubiquity of the bacterium in human feces. Further, since not all isolates are toxigenic, specific toxigenic strains that coexist with a larger population of non-toxigenic strains may be overlooked. Biochemical tests are also incapable of distinguishing different types of $C$. perfringens. As a consequence, traditional clinical diagnosis of enteric pathogens by conventional methods lack the competence for large-scale investigations and the adequate precision and sensitivity required for low-level sub-clinical detection. Several immunosorbent assays have also been developed, of which some are also commercially available for detection of clostridial toxins including C. perfringens toxins [20, 22, 23]; however, these assays are not as sensitive as traditional methods and often produce false-negative results [24-26]. Further, these toxin-specific immunosorbent assays may overlook the samples of those subjects who are carrying toxigenic bacterium but in whom the toxin is not produced [22]. Furthermore, the toxin may not be detected, for instance, if it is a modified toxin or neutralized by host factors [24]. Therefore, to avoid such discrepancies, the potential of PCR-based methods with specific gene targets has been explored. Rapid and specific detection has been achieved by molecular approaches based on PCR, and it has been used as a reliable tool to detect $C$. perfringens within complex microbial backgrounds such as complex food products and fecal samples [27-32]. However, since complex samples such as human feces contain numerous polymerase-inhibitory substances that affect the sensitivity of PCR reactions [33, 34], majority of the available methods require pure cultures or preincubation steps in order to enumerate lower counts $\left(<10^{5} \mathrm{cfu} / \mathrm{g}\right)$ of toxigenic strains of C. perfringens, particularly in the feces of asymptomatic subjects.

In this context, we developed a rapid and sensitive qPCR assay to detect and quantify $C$. perfringens directly in human fecal samples by using a novel primer pair targeting the chromosomally-located plc ( $\alpha$-toxin) gene. The assay was coupled with a commercially available PCR buffer Ampdirect ${ }^{\circ}$ Plus (Shimadzu, Japan) as a measure to allow more efficient PCR amplification by neutralizing the effect of inhibitory substances present in biological samples [35]. The method was validated for its specificity and sensitivity against various targeted (C. perfringens) and non-targeted (non-C. perfringens and non-clostridial species) bacterial strains, and also for detection efficiency and reproducibility in artificially inoculated fecal samples. The final step in the analytical validation of the assay was its application to detect and quantify $C$. perfringens in fecal samples from 345 apparently healthy Japanese subjects (infants, $n$ 124; adults, $n$ 221). In addition to $p l c$ gene, the samples were also analyzed for 16S rRNA and chromosomal cpe genes. Herein, we provide a specific, sensitive and rapid assay for quantitative enumeration of toxigenic C. perfringens in human feces.

\section{Methods}

\section{Primer design}

The $p l c$ gene was targeted for the design of primer. The sequence of the gene was procured from GenBank, National Center for Biotechnology Information (NCBI) (http://www.ncbi.nlm.nih.gov/genbank/). Multiple alignment of the gene sequences was performed with the CLUSTAL_X program (http://clustalx.software.informer.com) [36] by using plc gene sequences from more than 25 strains of $C$. perfringens including the three 
reference strains, ATCC $13124^{\mathrm{T}}$ (GenBank accession number: NC_008261; Gene ID: 4201274), Str. 13 (GenBank accession number: NC_003366; Gene ID: 988262) and SM101 (GenBank accession number: NC_008262; Gene ID: 4205371). After comparison of the sequences in silico, target sites for $C$. perfringens plc-specific detection were identified and a putative oligonucleotide primer set was designed following the primer designing instructions from user guide catalog (http://www3.ap pliedbiosystems.com/cms/groups/mcb_support/docume nts/generaldocuments/cms_041053.pdf). The primer was subsequently checked for potential cross-reactivity with the BLAST (Basic Local Alignment Search Tool) database search application (http://www.ncbi.nlm.nih.gov/ BLAST), and for preliminary sensitivity and specificity by qPCR with extracted DNA fractions from 30 Clostridium and non-clostridia strains (Table 1 and 2). For the analysis of cpe gene, the primer pair reported previously [37] was used to amplify a 154 bp product from the chromosomal cpe locus (Table 1). The details of $16 \mathrm{~S}$ rRNA gene-specific primer pair have previously been reported [38] (Table 1).

\section{Bacterial strains and culture conditions}

The bacterial strains used in the present investigation included 8 C. perfringens and 22 non-C. perfringens strains, as listed in Table 2. The strains were type strains either from the American Type Culture Collection (ATCC) or Japan Collection of Microorganisms (JCM). The strain C. perfringens C052-1 was previously isolated and characterized from human feces in the author's laboratory at Yakult Central Institute. All the Clostridia strains were routinely grown in modified Gifu anaerobic broth (Nissui Pharmaceutical Co., Ltd., Tokyo, Japan) supplemented with $1 \%$ glucose (Glu-mGAM) at $37{ }^{\circ} \mathrm{C}$ for $24 \mathrm{~h}$ under anaerobic conditions. All anaerobic manipulations were performed in an anaerobic glove box (Coy Laboratory Products Inc., Grass Lake, MI). Total bacterial cell counts were determined by DAPI staining, according to the method described previously [39].

\section{Primary treatment of fecal samples}

Fresh fecal specimens were collected from five healthy adult male subjects for spiking tests, and from 124 infants and 221 young adults for analytical validation of the qPCR assays (details of the subjects are provided in subsequent sections). Immediately after defecation, a spoonful of feces (0.5 to $1.0 \mathrm{~g})$ was collected into a fecal collection tube (Sarstedt AG \& Co., Numbrecht, Germany), and the tubes were stored at $-80{ }^{\circ} \mathrm{C}$ until use for the pretreatment for qPCR. Primary treatment of feces for total DNA extraction was done as follows. Each fecal sample was weighed, suspended in 9 volumes of sterile PBS (-) to make 10 -fold (v/w) dilution, and was washed twice with PBS (-) by centrifugation at $12,000 \times$ $g$ at $4{ }^{\circ} \mathrm{C}$ for $5 \mathrm{~min}$. About equal volume of glass beads (2.5 mm, diameter), as that of fecal sample, were added to the diluted samples, and the mixture was subjected to vigorous vortex to make a uniform fecal homogenate which was then divided into $200 \mu \mathrm{l}$ aliquots and stored at $-80{ }^{\circ} \mathrm{C}$ until DNA extraction.

\section{DNA extraction}

DNA extraction was performed according to the method previously described [40], with minor modifications. Briefly, the thawed sample $(200 \mu \mathrm{l}$ aliquots of pure cultures or primary treated fecal samples) was mixed with $250 \mu \mathrm{l}$ of extraction buffer $(100 \mathrm{mM}$ Tris- $\mathrm{HCl}, 40 \mathrm{mM}$ EDTA; pH 9.0), $50 \mu \mathrm{l}$ of $10 \%$ sodium dodecyl sulfate, $300 \mathrm{mg}$ of glass beads (diameter, $0.1 \mathrm{~mm}$ ), and $500 \mu \mathrm{l}$ of Tris-EDTA-saturated phenol, and the mixture was subjected to vigorous vortexing for $15 \mathrm{~min}$ using a ShakeMaster Auto BMS-A15 (Bio Medical Science Inc., Tokyo, Japan). After phenol-chloroform purification and isopropanol precipitation of the sample, the nucleic acid fraction was suspended in $0.1 \mathrm{ml}$ of TE ( $\mathrm{pH} 8.0)$.

\section{Real-time qPCR assay}

The specific primer sets for $16 \mathrm{~S}$ rRNA, plc and cpe gene (as described in Table 1) were used. For qPCR without Ampdirect ${ }^{\circ}$ plus (Shimadzu, Japan), each reaction mixture $(20 \mu \mathrm{l})$ was composed of $1 \times$ PCR buffer (TaKaRa Bio Inc., Shiga, Japan), each dNTP at a concentration of $200 \mu \mathrm{M}, \mathrm{MgCl}_{2}$ solution at a concentration of $2.5 \mathrm{mM}$, a 1:75,000 dilution of SYBR green I (BioWhittaker Molecular Applications, Rockland, ME), Takara Taq ${ }^{\mathrm{TM}}$ (TaKaRa Bio Inc., Shiga, Japan) at a concentration of

Table 1 C. perfringens targeted primers used in this study

\begin{tabular}{|c|c|c|c|c|c|c|}
\hline Target & Standard strain & Primer & Sequence $\left(5^{\prime}-3^{\prime}\right)$ & Product size (bp) & Annealing temp $\left({ }^{\circ} \mathrm{C}\right)$ & Reference \\
\hline \multirow[t]{2}{*}{ plc gene } & 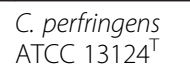 & Cper-plc508-F & CCGTTGATAGCGCAGGACA & & & \\
\hline & & Cper-plc508-R & CCCAACTATGACTCATGCTAGCA & 219 & 60 & This study \\
\hline \multirow[t]{2}{*}{ cpe gene } & C. perfringens & GAP11 & GGTTCATTAATTGAAACTGGTG & 154 & 55 & {$[37]$} \\
\hline & & GAP12 & AACGCCAATCATATAAATTACAGC & & & \\
\hline \multirow[t]{2}{*}{ 16S rRNA gene } & C. perfringens & s-Clper-F & GGGGGTTTCAACACCTCC & 170 & 60 & {$[38,74]$} \\
\hline & & CIPER-R & GCAAGGGATGTCAAGTGT & & & \\
\hline
\end{tabular}


Table 2 Results of specificity tests using p/c-and cpe-targeted primer sets

\begin{tabular}{|c|c|c|c|}
\hline \multirow[t]{3}{*}{ Taxon } & \multirow[t]{3}{*}{ Strain } & \multicolumn{2}{|c|}{ Reactions with the following primer sets } \\
\hline & & Cper-plc508-F/R & GAP11/12 \\
\hline & & (p/c-target) & (cpe-target) \\
\hline Clostridium perfringens & ATCC $13124^{\top}$ & + & - \\
\hline Clostridium perfringens & ATCC 9856 & + & - \\
\hline Clostridium perfringens & ATCC 3624 & + & - \\
\hline Clostridium perfringens & ATCC 3626 & + & - \\
\hline Clostridium perfringens & ATCC 12917 & + & + \\
\hline Clostridium perfringens & ATCC 14809 & + & + \\
\hline Clostridium perfringens & ATCC 27324 & + & - \\
\hline Clostridium perfringens & C052-1 & + & + \\
\hline Clostridium ramosum & JCM $1298^{\top}$ & - & - \\
\hline Clostridium innocuum & DSM $1286^{\top}$ & - & - \\
\hline Clostridium cocleatum & JCM $1397^{\top}$ & - & - \\
\hline Clostridium symbiosum & JCM $1297^{\top}$ & - & - \\
\hline Clostridium ghonii & $J C M 1400^{\top}$ & - & - \\
\hline Clostridium aminovalericum & JCM $11016^{\top}$ & - & - \\
\hline Clostridium indolis & JCM $1380^{\top}$ & - & - \\
\hline Clostridium paraputrificum & JCM $1293^{\top}$ & - & - \\
\hline Clostridium butylicum & JCM $1391^{\top}$ & - & - \\
\hline Clostridium difficile & DSM $1296^{\top}$ & - & - \\
\hline Clostridium sordellii & JCM $3814^{\top}$ & - & - \\
\hline Clostridium glycolicum & $J C M 1401^{\top}$ & - & - \\
\hline Clostridium lituseburense & JCM $1404^{\top}$ & - & - \\
\hline Clostridium bifermentans & JCM $1386^{\top}$ & - & - \\
\hline Blautia producta & $J C M 1471^{\top}$ & - & - \\
\hline Faecalibacterium prausnitzii & ATCC $27768^{\top}$ & - & - \\
\hline Bacteroides vulgatus & ATCC $8482^{\top}$ & - & - \\
\hline Collinsella aerofaciens & DSM $3979^{\top}$ & - & - \\
\hline Prevotella melaninogenica & ATCC $25845^{\top}$ & - & - \\
\hline Bifidobacterium longum & ATCC $15707^{\top}$ & - & - \\
\hline Clostridium innocuum & DSM $1286^{\top}$ & - & - \\
\hline Fusobacterium russii & ATCC $25533^{\top}$ & - & - \\
\hline
\end{tabular}

0.02 units/ $\mu$ l, TaqStart antibody (Clontech, Palo Alto, $\mathrm{CA})$ at a concentration of $5.5 \mathrm{ng} / \mu \mathrm{l}$, and $5 \mu \mathrm{l}$ template DNA. Each primer set was added at a final concentration of $0.2 \mu \mathrm{M}$. For qPCR with Ampdirect ${ }^{\bullet}$ plus (AmpqPCR), each reaction mixture $(20 \mu \mathrm{l})$ was composed of $1 \times$ Ampdirect $^{\oplus}$ plus buffer, a 1:75,000 dilution of SYBR green I, Takara Taq $^{\mathrm{TM}}$ at a concentration of 0.02 units/ $\mu \mathrm{l}$, TaqStart antibody at a concentration of $5.5 \mathrm{ng} / \mu \mathrm{l}$, and $5 \mu \mathrm{l}$ template DNA. Each primer set was added at a final concentration of $0.2 \mu \mathrm{M}$. The amplification program consisted of one cycle at $95{ }^{\circ} \mathrm{C}$ for $5 \mathrm{~min}$, followed by 50 cycles at $94{ }^{\circ} \mathrm{C}$ for $20 \mathrm{~s}, 55 / 60{ }^{\circ} \mathrm{C}$ for $20 \mathrm{~s}$, and $72{ }^{\circ} \mathrm{C}$ for $50 \mathrm{~s}$. The fluorescent products were detected at the last step of each cycle. For determination of specificity of the amplifications, a melting curve analysis was performed in concurrence with each PCR runs by slow heating at temperatures from 60 to $95{ }^{\circ} \mathrm{C}$, with fluorescence obtained at $0.2{ }^{\circ} \mathrm{C} / \mathrm{s}$. qPCR amplification and detection were performed in 96-well optical plates (Cat. No. 3754; Corning Inc. Life Sciences, Japan) with an ABI PRISM 7500 sequence detection system (version: 1.4.0; Applied Biosystems, Foster City, CA). The plates were sealed with optical-quality adhesive films (Cat. No. 547KTS-HC-P; Watson Bio-Lab Co., Ltd., Japan). The MIQE (Minimum Information for the publication of real-time Quantitative PCR Experiments) guidelines [41] 
were followed for the description of experimental designs and results.

\section{Determination of primer specificity}

The specificity of the newly-designed plc primer set and the reported cpe primer set was tested on several target and non-target reference strains, as listed in Table 2 . Total DNA fractions extracted from the bacterial cells of each strain at a dose corresponding to $10^{5}$ cells were assessed for qPCR by using each primer set. Using the standard curve from C. perfringens ATCC $13124^{\mathrm{T}}$ or C. perfringens ATCC 12917 obtained as described above, the amplified signal was judged to be positive when it was more than that of $10^{4}$ standard cells and negative when it was less than that of $10^{-1}$ standard cells. The amplified signal was defined as negative when the corresponding melting curve had a peak different from that of the standard strain. The specificity of $16 \mathrm{~S}$ rRNA genespecific primer has previously been reported by using Reverse Transcription-qPCR [38].

\section{Determination of qPCR sensitivity}

C. perfringens ATCC $13124^{\mathrm{T}}$ or C. perfringens ATCC 12917 was cultivated in Glu-mGAM broth. Bacterial counts were determined microscopically by DAPI staining and DNA was extracted from culture samples in the early stationary phase $(24 \mathrm{~h})$. Serial DNA dilutions corresponding to bacterial (DAPI) counts ranging from $10^{\circ}$ to $10^{5}$ cells were assessed by Amp-qPCR assays, and the standard curves were established. The range of DNA concentrations at which there was linearity with the $C_{q}$ value was confirmed $\left(R^{2}>0.99\right)$.

\section{Determination of bacterial counts by qPCR}

For identification of the target bacterial population in the fecal samples, $1 / 20,1 / 200,1 / 2,000$ portion of the DNA extracts and 1/2,000,1/20,000, 1/200,000 portion of the DNA extracts were subjected to Amp-qPCR and qPCR, respectively, and the $C_{q}$ values in the linear range of the assay $\left(10^{0}\right.$ to $10^{5}$ cells) were applied to the analytical curve generated in the same experiment to obtain the corresponding bacterial count in each nucleic acid sample, which was converted to the count per $g$ of feces. Multiple NTCs were included with every assay. The $C_{q}$ values and the corresponding copy numbers for standards were included in the standard curve construction when the $C_{q}$ values of standard were smaller than those of NTCs by 2 or more, and the LOD was defined as the smallest bacterial number in each standard curve.

\section{Quantification of C. perfringens spiked in human feces by qPCR}

Fresh fecal samples were collected from five healthy adult males (ages, 28, 37, 41, 42, and 48 years) whose samples had previously been verified by previously established 16S rRNA gene-specific assay to be Amp-qPCRnegative $\left(<10^{3}\right.$ cells/g feces) for $C$. perfringens [38]. The samples were subjected to the primary treatment as described above. It may be noted that for spiking tests, the samples were first suspended in 4 volumes of sterilized PBS (-) to make a 5-fold ( $\mathrm{v} / \mathrm{w})$ dilution and were then mixed with an equal amount of bacterial suspension to obtain a $10-$ fold $(\mathrm{v} / \mathrm{w})$ diluted fecal suspension. An overnight grown active culture of $C$. perfringens ATCC $13124^{\mathrm{T}}$ or $C$. perfringens ATCC 12917 was counted by DAPI staining and serially diluted in sterilized PBS (-) to make a series of concentrations from $2 \times 10^{7}$ to $2 \times$ $10^{2}$ cells $/ \mathrm{ml}$, and $500 \mu \mathrm{l}$ of these bacterial dilutions was spiked into corresponding $500 \mu \mathrm{l}$ of fecal homogenates to make final concentrations ranging from $1 \times 10^{8}$ to $1 \times$ $10^{3}$ cells/g of feces. DNA fractions were extracted from $200 \mu \mathrm{l}$ of each spiked sample and were assessed by qPCR and Amp-qPCR assays, as described above. The $C_{q}$ values obtained by the three primers were applied to the standard curve generated with serial dilution series of $C$. perfringens ATCC $13124^{\mathrm{T}}$ (16S rRNA gene and plc) or C. perfringens ATCC 12917 (cpe) DNA corresponding to $10^{0}$ to $10^{5}$ cells per reaction to determine the qPCR counts. A melting curve analysis was performed after amplification to distinguish the target from the non-targeted PCR products. For determination of the number of bacteria in fecal samples, three serial dilutions of each extracted DNA sample $(5 \mu \mathrm{l})$ were used for $\mathrm{qPCR}$, and the $C_{q}$ values in the linear range of the assay were applied to the standard curve generated in the same experiment to obtain the corresponding number of bacteria in each nucleic acid sample and then converted to the number of bacteria per gram of feces.

\section{Detection of $C$. perfringens in clinical samples}

The newly-developed $p l c$-specific Amp-qPCR assay was used to quantify $C$. perfringens in 345 fecal samples from apparently healthy infants ( $n$ 124; M 70; F 54; age: $167 \pm$ 3.3 days; age range: $161-178$ days) and young adults ( $n$ 221; M 153, F 68; age: $18.8 \pm 0.9$ years; age range: $18-22$ years). The infants' samples were obtained from Gonohashi Obstetrics and Gynecology Hospital, Koto-ku, Tokyo; and the adults' samples were from students enrolled at Juntendo University Graduate School of Sports Medicine, Tokyo. Informed written consent was obtained from all the subjects or their legal representatives. The study designs of infant and adult subjects were approved by the ethical committees of Yakult Central Institute and Juntendo University Graduate School of Medicine, respectively. Immediately after defecation, samples were collected as per the method described above. The infant samples were kept at $4{ }^{\circ} \mathrm{C}$ in a cooling box with refrigerants and sent immediately to Yakult 
Central Institute where these were stored at $4{ }^{\circ} \mathrm{C}$ until the primary treatment. The adults' samples were stored at $-80{ }^{\circ} \mathrm{C}$ at the site of collection, and were transported in a frozen state to the Yakult Central Institute where these were stored at $-80{ }^{\circ} \mathrm{C}$ until use for the primary treatment. The samples were subjected to the primary treatment and nucleic acid extraction, as described above. DNA samples were finally subjected to the newly-developed Amp-qPCR assay by using plc-specific primer pair, and were also analyzed simultaneously by using a previously validated $16 \mathrm{~S}$ rRNA gene-specific primer pair for comparison purposes and also by cpe-specific primer pair for the analysis of enterotoxigenic strains (Table 1) by Amp-qPCR.

\section{Statistical analyses}

Results of log-transformed bacterial count $\left(\log _{10}\right.$ cells/g feces) are expressed as mean \pm standard deviation. The program R (http://www.r-project.org) was used for statistical analyses. Mann-Whitney $U$ test and Fisher's exact probability test were used to calculate the mean differences in the fecal counts and the detection rates (prevalence), respectively. $P<0.05$ was considered statistically significant.

\section{Results}

\section{Specificity of the primer sets}

The specificity of plc- and cpe-targeted primers was tested in vitro by using DNA fractions extracted from several target and non-target bacterial strains corresponding to $10^{5}$ bacterial cells. Data providing the specificity of the designated primer sets is presented in Table 1 . The qPCR results showed high specificity of the plc primer set for the detection of $C$. perfringens at the species level. There was no amplification with any of the DNA samples extracted from non-target microorganisms, thereby authenticating the specificity of the primer pair designed in silico. In case of cpe-targeted primer, the assay yielded positive reaction only with three strains i.e. ATCC 12917, ATCC 14809 and C052-1 that are known to harbor the functional chromosomal cpe gene (Table 1). C. perfringens ATCC 27324 also carry cpe gene on plasmid, but this gene is non-functional due to some specific mutation [42]. Notably, the cpe-specific primer (GAP 11/12) did not react with this strain (Table 1), verifying that this primer targets the conserved chromosomal sequence and hence detects only the functional cpe gene.

\section{Determination of Amp-qPCR sensitivity}

The sensitivity of three Amp-qPCR (qPCR using Ampdirect $^{\circ}$ Plus buffer) assays was tested with serial dilutions of DNA samples extracted from respective pure cultures of $C$. perfringens strains. When the $C_{q}$ values were plotted against the $\log _{10}$ values of the initial number of C. perfringens cells in the qPCR to generate a standard curve, a standard linearity of regression curves was observed (Fig. 1). The counts of different $C$. perfringens strains in the pure culture obtained by DAPI staining ( $x$ axis) showed good correlation with the corresponding $C_{q}$ values obtained by the respective Amp-qPCR assay ( $y$ axis) (Fig. $1 ; R^{2}>0.99$ ). All raw data i.e., $C_{q}$ of the NTCs and LOD, analytical curve and PCR efficiency are provided in Additional file 1: Table S1 in Supplementary Material.

\section{Quantitative detection of C. perfringens spiked in fecal samples}

Cell counts from the $24 \mathrm{~h}$ old cultures were determined by DAPI staining using fluorescent microscopy, and serial dilutions of respective cultures were spiked separately into the fecal samples from five healthy volunteers who had been confirmed in advance by previously established $16 \mathrm{~S}$ rRNA gene-specific assay to be Amp-qPCR-negative for $C$. perfringens $\left(<10^{3}\right.$ bacterial cells/g feces) in their feces [38]. The C. perfringens counts obtained by qPCR as well as Amp-qPCR assays were well correlated with the expected values $\left(R^{2}>0.98\right.$; Fig. 2). The $\mathrm{qPCR}$ and Amp-qPCR yielded comparable slopes of the fitted curves, indicating that the two reactions gave similar amplification efficiencies. However, while the LOD of all the three qPCR assays (without Ampdirect ${ }^{\circ}$ Plus) was about $10^{5}$ bacterial cells/g feces, it was lowered to $10^{3}$ bacterial cells/g with the use of Ampdirect ${ }^{\circ}$ Plus PCR buffer (Amp-qPCR), indicating that the Amp-qPCR assays were about 100 times more sensitive than the qPCR assays for the quantitative detection of $C$. perfringens in fecal samples. Apparently, due to its ability to neutralize the effect of PCR inhibitors, the inclusion of Ampdirect ${ }^{\circ}$ Plus buffer led to the use of more amount of stool DNA extract (maximum template amount of $1 / 20$ in Amp-qPCR vs. $1 / 2,000$ in $q P C R$ ) and hence a higher detection sensitivity. The counts of spiked C. perfringens ( $x$ axis) and the corresponding counts determined by Amp-qPCR assay ( $y$ axis) correlated well over the bacterial concentrations ranging from $10^{3}$ to $10^{8}$ bacterial cells/g of feces $\left(R^{2}>0.99\right.$; Fig. 2). These results indicated the efficiency and validity of these Amp-qPCR assays for the specific quantification of 16S rRNA, plc and cpe genes of $C$. perfringens in human feces.

\section{Detection of $C$. perfringens in stool samples}

The Amp-qPCR assays were finally performed to enumerate the populations of $C$. perfringens in fecal samples from apparently healthy infants $(n$ 124) and adult subjects ( $n$ 221). Table 3 shows the average counts and detection rates (\%) of C. perfringens in the two cohorts, as determined by the Amp-qPCR assays. With the use of 


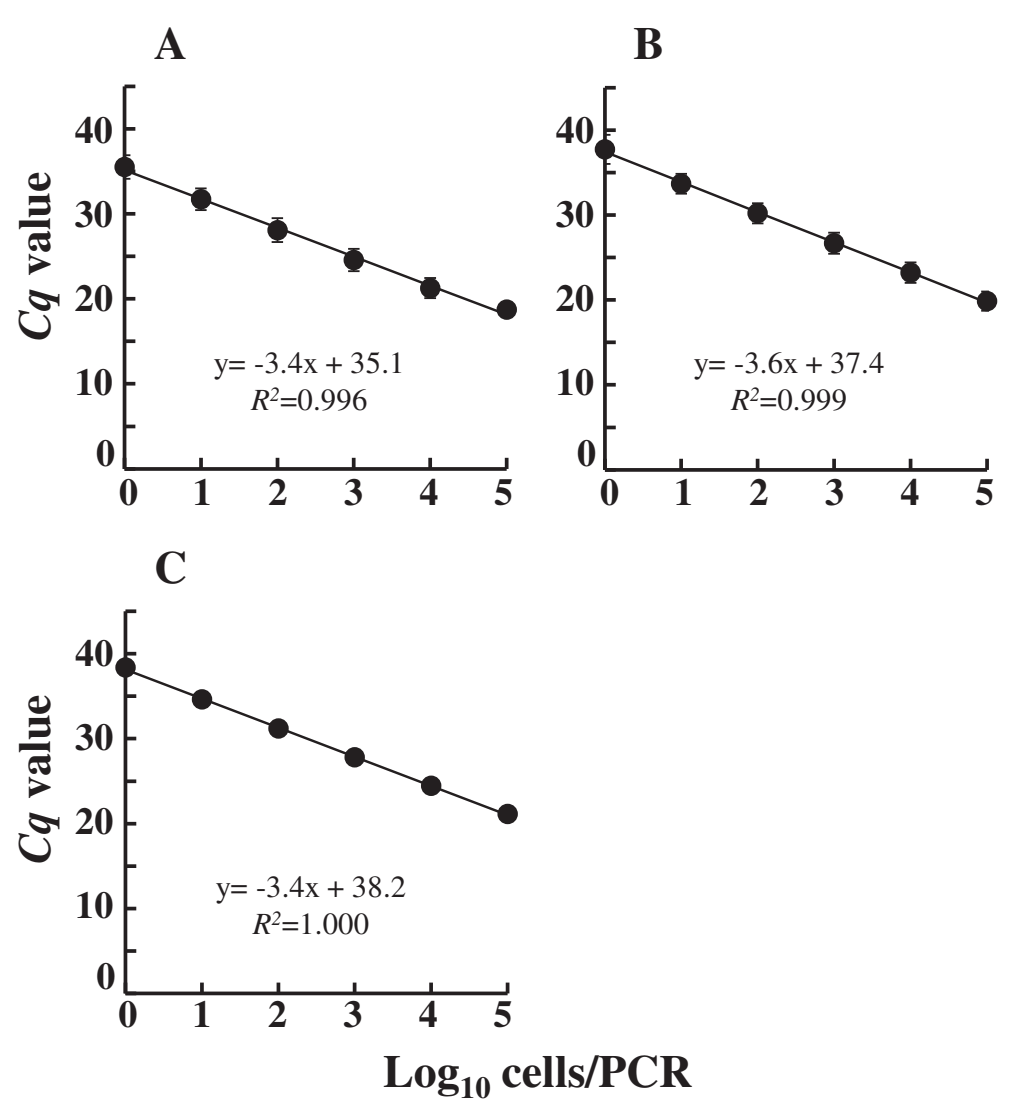

Fig. 1 Standard curves representing the quantitative detection of reference strains of C. perfringens by Amp-qPCR assay. C. perfringens ATCC 13124', ATCC 9856, ATCC 3624, ATCC 3626, ATCC 12917, ATCC 14809, ATCC 27324, and CS 052-1 were cultivated separately in Glu-mGAM. DNA fractions were extracted from the culture samples in the early stationary phase $(24 \mathrm{~h})$, and bacterial counts were determined microscopically with DAPI staining. 10-fold serial dilutions of DNA corresponding to the bacterial counts ranging from $10^{\circ}$ to $10^{5}$ bacterial cells were assessed by 165 rRNA gene-specific $\mathbf{a}$, plc-specific $\mathbf{b}$, and cpe-specific $\mathbf{c}$ Amp-qPCR assays. The Cq values obtained were plotted against the $\log _{10}$ number of bacterial cells subjected to each reaction. Data are expressed as means and standard deviations of the results from 7 strains (ATCC 13124 ${ }^{\top}$, ATCC 9856, ATCC 3624, ATCC 3626, ATCC 12917, ATCC 14809, and ATCC 27324) in the 165 rRNA gene-specific and plc-specific primer sets, and 3 strains (ATCC 12917, ATCC 14809, and CS 052-1) in the cpe-specific primer set

newly developed plc-specific Amp-qPCR assay, C. perfringens was detected ( $>10^{3}$ bacterial cells/g feces) in $36 \%$ (44/124) of the infants and $33 \%(70 / 221)$ of the adults, and its count ranged widely $\left(10^{3}\right.$ to $10^{7}$ bacterial cells/g feces) among each of the cohorts. The average $p l c^{+} C$. perfringens count was significantly $(p=0.00008)$ higher in infants $\left(6.0 \pm 1.5 \log _{10}\right.$ bacterial cells/g), as compared to that in adults $\left(4.8 \pm 1.2 \log _{10}\right.$ bacterial cells $/ g$ ). The mean counts obtained by $p l c$-specific Amp-qPCR assay were comparable with those obtained by $16 \mathrm{~S}$ rRNA-targeted Amp-qPCR assay (Table 2). Accordingly, matching with the results of $p l c$-specific assay, the average $C$. perfringens count analyzed by $16 \mathrm{~S}$ rRNAtargeted assay was also significantly higher $(p=0.000001)$ in the infant cohort $\left(6.4 \pm 1.3 \log _{10}\right.$ bacterial cells/g), as compared to that in the adult cohort $\left(4.8 \pm 1.2 \log _{10}\right.$ bacterial cells/g). Although, at individual level, slight numerical differences between the counts analyzed by the two assays were observed in few samples (Additional file 2: Table S2) which can explain the minor difference in the detection rates analyzed by the two assays (Table 2), these differences were always less than one log value and could be attributed to the minor differences in the specificity and sensitivity of two different primers towards two different genes in different PCR reactions.

Detection of enterotoxin (cpe) gene-positive C. perfringens The samples from the two cohorts were also analyzed by cpe-specific Amp-qPCR assay for the quantification of enterotoxigenic $C$. perfringens (Table 2). The carriage rate of cpe-positive $C$. perfringens was $10 \%(12 / 124)$ in the infants which was significantly $(p=0.0004)$ higher as compared to that in the adults $(1 \% ; 3 / 221)$. The average fecal count of cpe-positive $C$. perfringens in these positive samples was insignificantly $(p=0.536)$ higher in the infants $\left(5.9 \pm 1.9 \log _{10}\right.$ bacterial cells/g feces), as compared 

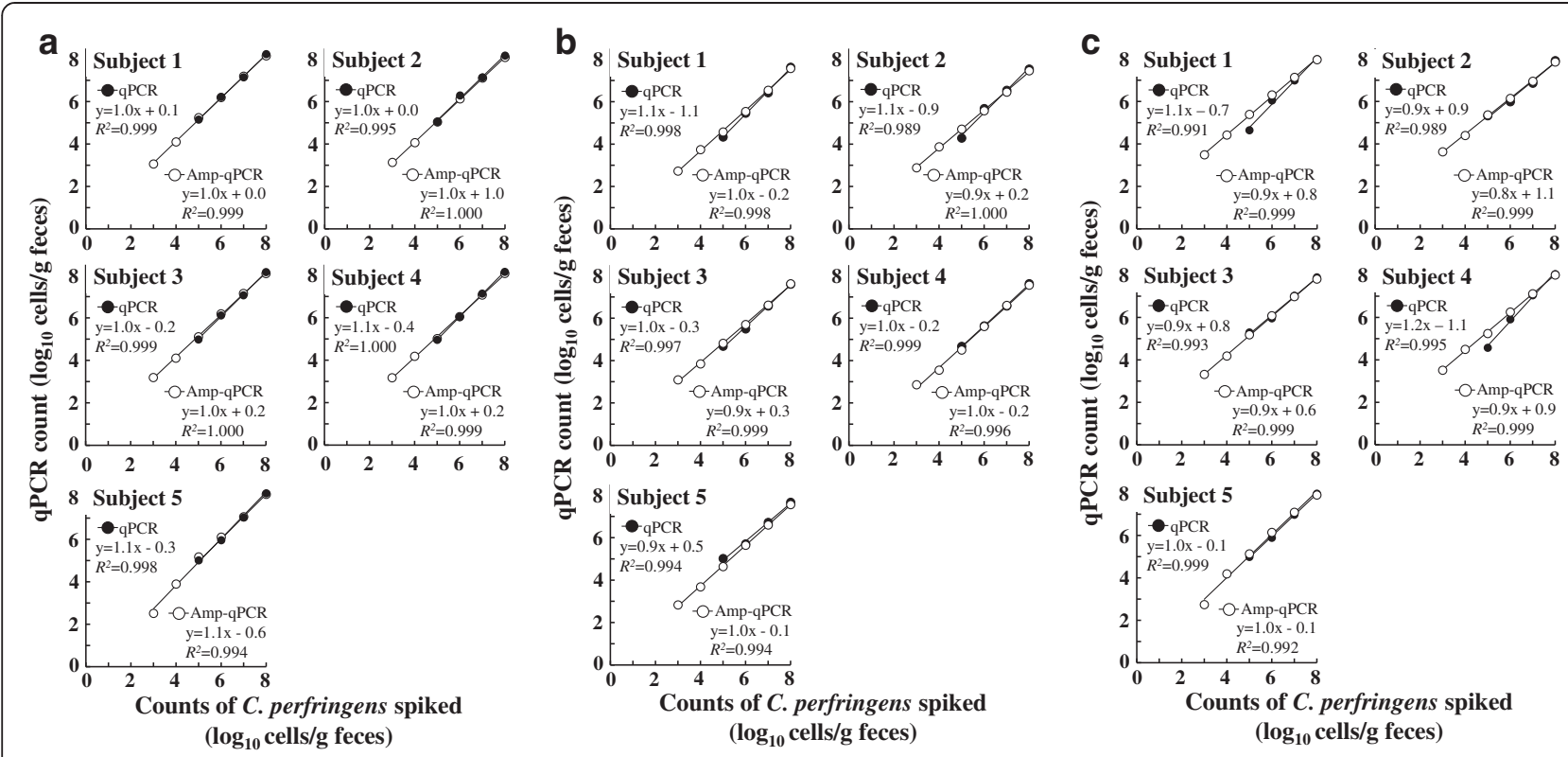

Fig. 2 Quantitative detection of C. perfringens spiked in human feces by a 165 rRNA gene-specific, b plc-specific, and c cpe-specific qPCR assays with or without Ampdirect ${ }^{\oplus}$ Plus buffer. Strain ATCC $13124^{\top}$ was used as reference for $16 \mathrm{~S}$ rRNA gene- and plc-specific assays, and ATCC 12917 was used for cpe-specific assay

to that in the adults $\left(4.8 \pm 0.8 \log _{10}\right.$ bacterial cells/g feces). As expected, all the cpe-positive samples were also found to be positive by plc- and $16 \mathrm{~S}$ rRNA gene-specific assays, and in most cases, the counts analyzed by cpe-specific assay were comparable to the counts analyzed by plc- and 16S rRNA gene-specific assays. In few cases, however, the count of cpe-positive C. perfringens was found to be lower than the counts analyzed by plc- or $16 \mathrm{~S}$ rRNA-specific assays (Additional file 2: Table S2), which may be due to the presence of more than one strains of $C$. perfringens in these subjects.

\section{Discussion}

In order to serve as an analytical tool to investigate the intestinal carriage and prevalence of $\alpha$-toxigenic and enterotoxigenic C. perfringens, we developed a quantitative real-time PCR assay for rapid (within 4-5 h) and sensitive detection of this subdominant but important gut inhabitant in human feces. The assay had high analytical specificity as well as sensitivity and should become an efficient, rapid and sensitive alternate method to conventional methods for the detection and quantification of $C$. perfringens directly from pure cultures, feces and other complex samples. Data on linear range as well as amplification efficiency is important in order to authenticate the precision of qPCR for quantitative enumerations. With a quantitative detection limit of $10^{3}$ bacterial cells/g feces, a linear range of six to seven orders of magnitude and an acceptable reaction efficiency, our Amp-qPCR assays demonstrated an accurate quantification of $C$. perfringens from DNA extracted from pure culture or spiked fecal homogenates (Figs. 1, 2; Additional file 1: Table S1). We have already reported in our previous study of $C$. difficile that our in-house validated nucleic acid extraction method could extract RNA from the whole clostridial cells, i.e., in both the states,

Table 3 Quantitative detection of C. perfringens in stool samples from healthy infants and young adults by Amp-qPCR assays targeting $16 \mathrm{~S}$ rRNA, plc and cpe genes

\begin{tabular}{|c|c|c|c|c|}
\hline \multirow[t]{3}{*}{ Target } & \multicolumn{2}{|l|}{ Infant aged 6 months } & \multicolumn{2}{|l|}{ Young adult } \\
\hline & \multicolumn{2}{|l|}{$(n=124)$} & \multicolumn{2}{|l|}{$(n=221)$} \\
\hline & Bacterial count ( $\log _{10}$ bacterial cells/g feces) ${ }^{a}$ & Detection rate $(\%)$ & Bacterial count $\left(\log _{10}\right.$ bacterial cells/g feces) ${ }^{a}$ & Detection rate $(\%)$ \\
\hline 16S rRNA gene & $6.4 \pm 1.3$ & 35 & $4.8 \pm 1.2^{\mathrm{b}}$ & 31 \\
\hline plc & $6.0 \pm 1.5$ & 36 & $4.8 \pm 1.2^{b}$ & 33 \\
\hline cpe & $5.9 \pm 1.9$ & 10 & $4.8 \pm 0.8$ & $1^{c}$ \\
\hline
\end{tabular}

aData are expressed as the means and standard deviations

${ }^{\mathrm{b}} p<0.05$ (vs. Infant aged 6 months), Mann-Whitney $U$ test

${ }^{c} p<0.05$ (vs. Infant aged 6 months), Fisher's exact probability test 
vegetative cells as well as spores [43]. Although we used DNA material in the present study, we followed same steps for the mechanical disruption of cells and for purification and precipitation of the nucleic acid material. Thus, our assay could detect whole bacterial cells of C. perfringens in feces and should be suitable for bacterial quantification irrespective of the bacterial growth phase. Overall, the assays developed in this study demonstrates threefold advantage: (a) high detection sensitivity of up to $10^{3}$ bacterial cells/g feces (which is significant for the detection of a subdominant gut microbe), (b) targeting chromosomal toxin gene (which is considerably important in context of a potential opportunistic pathogen), and (c) extraction of nucleic acids directly from feces (which makes the assay comparatively rapid). These assays were also used to quantify $C$. perfringens in samples from 124 infants and 221 adult subjects. The counts of $C$. perfringens in many subjects were found to be in a low range (i.e., $10^{3}-10^{4}$ bacterial cells/g feces), signifying the importance of lower detection limit of $10^{3}$ bacterial cells/g feces of our assays for the investigation of fecal carriage of toxigenic C. perfringens, particularly in asymptomatic subjects. To our knowledge, this is the first report (a) to validate a culture-independent qPCR assay to quantify $\alpha$-toxigenic and enterotoxigenic $C$. perfringens in human feces with an analytical sensitivity of $10^{3}$ bacterial cells/g feces, and (b) to report the intestinal carriage of these toxigenic C. perfringens strains in healthy Japanese infants and adults.

The fecal carriage of $C$. perfringens has earlier been studied (mainly in context to food-borne outbreaks), but the information about the toxigenic strains in asymptomatic subjects is limited [44-47]. It has generally been observed that healthy people carry less than $10^{5} \mathrm{C}$. perfringens $\mathrm{cfu} / \mathrm{g}$ feces while patients may carry $10^{6}$ or more cfu/g [44-47]. According to our data, C. perfringens may be present as commensal in the order of $10^{6}-10^{8}$ bacterial cells/g feces even among healthy subjects. We detected a plc C. perfringens count of more than $10^{6}$ bacterial cells/g in $21.7 \%$ infants and $7.2 \%$ adult subjects. This finding of higher carriage of $C$. perfringens, as compared to the previous studies, may be attributed to different study populations and/ or to the differences in detection sensitivities of different methods used. We targeted the $\alpha$-toxin gene to make the assay specific for all the toxigenic $C$. perfringens strains (particularly in human feces), since $\alpha$-toxin is produced by almost all the strains of $C$. perfringens and has been implicated in numerous gastrointestinal illnesses $[4,17,48]$. The counts analyzed by plc- and $16 \mathrm{~S}$ rRNA gene-specific assays were comparable (Table 2), indicating that all the $C$. perfringens strains detected in this study harbored the $\alpha$-toxin gene. This finding is consistent with those of prior studies [11, 17, 18, 30, 49]. Enterotoxigenic $C$. perfringens is responsible for nearly
$70 \%$ of C. perfringens food-poisoning outbreaks and $20 \%$ of all non-food-borne gastrointestinal diseases [17, 50-53]. However, its ecology still remains underexplored, because of the widespread environmental distribution of $C$. perfringens, a very low ratio of $c p e^{+}$ strains, and inability to quantify low count by majority of conventional methods $\left(<10^{5}\right.$ bacterial cells/g) of toxigenic strains [5]. In this context, our sensitive culture-independent assays could be particularly important in clinical diagnosis or epidemiological investigation. Since $\mathrm{cpe}^{+}$strains are also implicated in antibiotic-associated diarrhea, our assay should also find application in the analysis of such cases.

In our study, the average $p l c^{+} C$. perfringens count in infant cohort was found to be significantly higher than that in adult subjects (Table 2). Furthermore, the prevalence of $c p e^{+}$C. perfringens was also significantly higher than that in adult subjects (Table 2). Generally, about $1-5 \%$ of $C$. perfringens isolates produce enterotoxin $[17,52,54,55]$, however, in our study, the proportion of cpe-positive subjects out of the C. perfringens-positive ones was $27 \%$ in infants, which was significantly $(p=0.001)$ higher as compared to that in adult subjects (4\%). This finding of higher fecal carriage of $c p e^{+}$C. perfringens, particularly in infants, as compared to previous studies, may again be due to the differences in detection sensitivities of different methods used and/ or different study populations, since previous studies were mainly based on C. perfringens pure cultures or isolates from foods products and adult subjects. Nonetheless, the information on the occurrence of high population levels of toxigenic C. perfringens in infants' gut is particularly relevant given the importance of such opportunistic pathogens in hosts with immature or compromised immune system [56-58]. It is well known that $C$. perfringens can colonize the infant gut in early postnatal period $[59,60]$, however it remains to be identified if the source of toxigenic $C$. perfringens strains in infants is from mother, hospital, foods or from surrounding environment, people, pets etc. Although C. perfringens enterotoxin occasionally causes diarrhea, most infants remain healthy and hence may be considered as asymptomatic carrier of toxic pathogen [52]. Nevertheless, further investigations are needed to elucidate why and how the prevalence of this pathogen diminishes as these infants grow up. It might be correlated to the maturation of the gastrointestinal microbial ecosystem and the associated immune system from infancy to adulthood [60-65], given that $C$. perfringens has been found to be more abundant in neonates and elderly than in adults $[28,66,67]$.

We noticed that the counts of $c p e^{+} C$. perfringens varied widely from $10^{3}$ to $10^{8}$ cells/g feces; and in most cases, the counts analyzed by cpe-, plc- or $16 \mathrm{~S}$ rRNAspecific assays were comparable. Given the usefulness of 
fecal counts of $c p e^{+}$C. perfringens, particularly the counts of $>10^{5}$ or $>10^{6} \mathrm{cfu} / \mathrm{g}$, in the etiology of associated diseases [68], our findings of higher counts of $c p e^{+}$ C. perfringens in some healthy subjects may be an interesting target for future studies. Further, the differences in the counts analyzed by plc-and cpe-specific assays in some samples indicate that the intestinal carriage of $C$. perfringens may be diverse and that some healthy subjects may also act as potential reservoir of more than one C. perfringens strains. Such existence of $c p e^{+}$C. perfringens has earlier been reported $[17,52,53]$; however, the significance of such human reservoirs in context to the disease/ risk transmission remains to be comprehended. While it remains uncertain whether toxigenic $C$. perfringens strains are primary pathogens or secondary intruders of injured intestinal mucosae, from our data of healthy subjects, it appears implausible that these strains are primary gastrointestinal pathogens. However, it cannot be ruled out that some healthy subjects may serve as a reservoir for $\mathrm{plc}^{+}$and $c p e^{+} \mathrm{C}$. perfringens and hence may be more prone to developing $C$. perfringens-associated diseases, particularly in case of impaired intestinal mucosa and immunity or dysbiosis.

Several assays have earlier been developed for the detection of C. perfringens; however, most of these were mainly targeted for contaminated food products $[13,69,70]$. For example, the real-time PCR method developed by Fukushima et al. [69] could detect $10^{1}$ to $10^{2} \mathrm{cfu} / \mathrm{g}$ of food-borne pathogens in contaminated samples, but the PCR assay was preceded by a combination of filtration and low- and high-speed centrifugation protocols for the separation and concentration of bacteria from contaminated food samples such as chicken, pork, beef etc. and may not be competently applicable to human feces due to complex background microbiota, inhibitory substances and different matrixes. The assay developed by Kaneko et al. [13] could detect $>10^{3} \mathrm{cfu} / \mathrm{g}$ of cpe-positive $C$. perfringens in meat samples, but it required enrichment culture specimens of spiked samples. dela Cruz et al. [29] developed a rapid real-time fluorescence resonance energy transfer PCR targeting plc and cpe genes of C. perfringens. However, the assay could detect about 20 copies of target sequence per PCR, whereas our assay could detect even a single copy per PCR using pure culture. Few studies have also targeted bacterial detection from feces of animals such as pigs and poultry, but the detection limit of these assays was about $10^{4} \mathrm{cfu} / \mathrm{g}$ feces $[71,72]$. To detect $C$. perfringens in cattle feces, Gurjar et al. [73] developed a multiplex PCR assay with a detection limit of $30 \mathrm{pg}$ and $5 \mathrm{pg}$ of DNA for plc and cpe genes, respectively; however, the assay required pre-enrichment of the fecal samples to detect such low levels. Rinttila et al. [31] developed an array of real-time PCR methods for the analysis of 12 enteric pathogens including alpha-toxigenic $C$. perfringens from the human feces; however, the detection limit was set to $10^{4}$ bacterial genomic equivalents per gram of sample. In these contexts, our assay should be particularly advantageous for large-scale investigations of epidemiology and gut microbial ecology involving human samples since it can detect as low as $10^{3}$ toxigenic C. perfringens bacterial cells per gram of human feces without requiring any culturing step.

In summary, we have provided a novel qPCR assay for sensitive quantification of $C$. perfringens in human feces. We believe that the assay will represent a valuable analytical tool to quantify this subdominant but significant member of gut microbiota in human samples and will help in enhancing our understanding of its prevalence or pathogenesis. In addition, the assay should also be utilized in circumstances beyond fecal samples, and expedited detection should also be applicable in assessing foods, water, blood and other biological/ environmental samples. It is a limitation of our study that we did not examine C. perfringens-specific toxins, antitoxins or their bioactivities, and hence further studies on healthy and diseased subjects should be able to elucidate the clinical significance of high carriage of toxigenic C. perfringens strains in context to gastrointestinal health and microbiota.

\section{Additional files}

Additional file 1: Table S1. Standard curve information. (PDF $13 \mathrm{~kb}$ )

Additional file 2: Table S2. Quantitative data of $C$. perfringens count in stool samples from healthy infants and young adults by Amp-qPCR assays targeting $16 \mathrm{~S}$ rRNA, plc and cpe genes. (PDF 52 kb)

\section{Abbreviations}

Amp: Ampdirect ${ }^{\circledR}$ Plus PCR buffer; Cq: Quantification cycle; Cpe: C. perfringens enterotoxin; DAPI: 4',6-diamidino-2-phenylindole; JCM: Japan Collection of Microorganisms; LOD: Limit of detection; MIQE: Minimum Information for the publication of real-time Quantitative PCR Experiments; NTC: No-template control; PCR: Polymerase chain reaction; qPCR: Quantitative PCR; RTqPCR: Reverse transcriptase quantitative PCR; plc: Phospholipase C.

\section{Competing interests}

$\mathrm{RN}$ is supported by postdoctoral research fellowship from Juntendo University. KO, HT, KM, TT, KN are employees of Yakult Honsha Co., Ltd. YS, KK, SN and YY have received research grants from Yakult Honsha Co., Ltd. The funder did not have any additional role in the study design, data collection, analysis, decision to publish, or preparation of the manuscript. The authors declare that they have no competing interests.

\section{Authors' contributions}

Conceptualized and designed the study: RN, KO, HT, KN, YY. Performed the experiments: RN, KO. Coordinated the collection of samples: HT, YS, KK. Analyzed the data: RN, KO. Interpreted the data: RN, KO, HT, KN, YY. Drafted the manuscript: $R N, K O$. Critically reviewed and edited the manuscript: $H T$, $\mathrm{KM}, \mathrm{T}, \mathrm{KN}, \mathrm{SN}, \mathrm{YY}$. Approved the final version: RN, KO, HT, KM, T, $K N, Y S$, KK, SN, YY.

\section{Acknowledgements}

This work was financially supported by Yakult Honsha Co., Ltd., Japan. The authors wish to thank all the participating clinicians, colleagues and volunteers for help and cooperation during this study. 


\section{Author details}

${ }^{1}$ Probiotics Research Laboratory, Juntendo University Graduate School of Medicine, Tokyo, Japan. ${ }^{2}$ Yakult Central Institute, Tokyo, Japan. ${ }^{3}$ Yakult Honsha European Research Center for Microbiology, Ghent-Zwijnaarde, Belgium. ${ }^{4}$ Department of Sports Science, Juntendo University School of Health and Sports Sciences, Chiba, Japan. ${ }^{5}$ Gonohashi Obstetrics and Gynecology Hospital, Tokyo, Japan. 'Department of Pediatrics, School of Medicine, Tokyo Women's Medical University, Tokyo, Japan.

\section{Received: 14 May 2015 Accepted: 8 October 2015}

\section{Published online: 19 October 2015}

\section{References}

1. Canard B, Saint-Joanis B, Cole ST. Genomic diversity and organization of virulence genes in the pathogenic anaerobe Clostridium perfringens. Mol Microbiol. 1992;6:1421-9.

2. Smedley JG, Fisher DJ, Sayeed S, Chakrabarti G, McClane BA. The enteric toxins of Clostridium perfringens. Rev Physiol Biochem Pharmacol. 2004;152:183-204.

3. McDonel JL. Clostridium perfringens toxins (type A, B, C, D, E). Pharmacol Ther. 1980;10:617-55.

4. Sakurai J, Nagahama M, Oda M. Clostridium perfringens alpha-toxin: characterization and mode of action. J Biochem. 2004;136:569-74.

5. Miyamoto K, Li J, McClane BA. Enterotoxigenic Clostridium perfringens: detection and identification. Microbes Environ. 2012;27:343-9.

6. Awad MM, Ellemor DM, Boyd RL, Emmins JJ, Rood Jl. Synergistic effects of alpha-toxin and perfringolysin $\mathrm{O}$ in Clostridium perfringens-mediated gas gangrene. Infect Immun. 2001;69:7904-10.

7. O'Brien DK, Melville SB. Effects of Clostridium perfringens alpha-toxin (PLC) and perfringolysin $\mathrm{O}$ (PFO) on cytotoxicity to macrophages, on escape from the phagosomes of macrophages, and on persistence of $C$. perfringens in host tissues. Infect Immun. 2004;72:5204-15.

8. Bennett SD, Walsh KA, Gould LH. Foodborne disease outbreaks caused by Bacillus cereus, Clostridium perfringens, and Staphylococcus aureus - United States, 1998-2008. Clin Infect Dis. 2013;57:425-33.

9. Grass JE, Gould LH, Mahon BE. Epidemiology of food-borne disease outbreaks caused by Clostridium perfringens, United States, 1998-2010. Foodborne Pathog Dis. 2013;10:131-6.

10. Hatheway CL. Toxigenic clostridia. Clin Microbiol Rev. 1990;3:66-98.

11. Deguchi A, Miyamoto K, Kuwahara T, Miki Y, Kaneko I, Li J, et al. Genetic characterization of type A enterotoxigenic Clostridium perfringens strains. PLoS One. 2009;4:e5598.

12. Miyamoto K, Wen Q, McClane BA. Multiplex PCR genotyping assay that distinguishes between isolates of Clostridium perfringens type A carrying a chromosomal enterotoxin gene (cpe) locus, a plasmid cpe locus with an IS1470-like sequence, or a plasmid cpe locus with an IS1151 sequence. J Clin Microbiol. 2004;42:1552-8.

13. Kaneko I, Miyamoto K, Mimura K, Yumine N, Utsunomiya H, Akimoto S, et al. Detection of enterotoxigenic Clostridium perfringens in meat samples by using molecular methods. Appl Environ Microbiol. 2011;77:7526-32

14. Komatsu H, Inui A, Sogo T, Fujisawa T. Clostridium perfringens. Nihon Rinsho. 2012;70:1357-61.

15. Hauschild AHW. Criteria and procedures for implicating Clostridium perfringens in food-borne outbreaks. Can J Public Health. 1975;66:388-92

16. Shandera WX, Tacket CO, Blake PA. Food poisoning due to Clostridium perfringens in the United States. J Infect Dis. 1983;147:167-70.

17. Carman RJ, Sayeed S, Li J, Genheimer CW, Hiltonsmith MF, Wilkins TD, et al. Clostridium perfringens toxin genotypes in the feces of healthy North Americans. Anaerobe. 2008;14:102-8.

18. Lakshminarayanan B, Harris HM, Coakley M, O'Sullivan O, Stanton C, Pruteanu $\mathrm{M}$, et al. ELDERMET consortium. Prevalence and characterization of Clostridium perfringens from the faecal microbiota of elderly Irish subjects. J Med Microbiol. 2013;62:457-66.

19. Peterson LR, Kelly PJ, Nordbrock HA. Role of culture and toxin detection in laboratory testing for diagnosis of Clostridium difficile-associated diarrhea. Eur J Clin Microbiol Infect Dis. 1996;15:330-6.

20. Lindstrom M, Keto R, Markkula A, Nevas M, Hielm S, Korkeala H. Multiplex PCR assay for detection and identification of Clostridium botulinum types $A, B, E$, and $F$ in food and fecal material. Appl Environ Microbiol. 2001;67:5694-9.
21. Delmee M, Van Broeck J, Simon A, Janssens M, Avesani V. Laboratory diagnosis of Clostridium difficile-associated diarrhoea: a plea for culture. J Med Microbiol. 2005;54:187-91.

22. Asha NJ, Wilcox MH. Laboratory diagnosis of Clostridium perfringens antibiotic-associated diarrhoea. J Med Microbiol. 2002;51:891-4.

23. Snell H, Ramos M, Longo S, John M, Hussain Z. Performance of the TechLab C. DIFF CHEK-60 enzyme immunoassay (EIA) in combination with the C. difficile Tox A/B II ElA kit, the Triage C. difficile panel immunoassay, and a cytotoxin assay for diagnosis of Clostridium difficile-associated diarrhea. J Clin Microbiol. 2004:42:4863-5.

24. Birkhead G, Vogt RL, Heun EM, Snyder JT, McClane BA. Characterization of an outbreak of Clostridium perfringens food poisoning by quantitative fecal culture and fecal enterotoxin measurement. J Clin Microbiol. 1988;26:471-4.

25. Modi N, Wilcox MH. Evidence for antibiotic induced Clostridium perfringens diarrhea. J Clin Pathol. 2001;54:748-51.

26. Turgeon DK, Novicki TJ, Quick J, Carlson L, Miller P, Ulness B, et al. Six rapid tests for direct detection of Clostridium difficile and its toxins in fecal samples compared with the fibroblast cytotoxicity assay. J Clin Microbiol. 2003:41:667-70.

27. Mackay IM. Real-time PCR, in the microbiology laboratory. Clin Microbiol Infect. 2004;10:190-212

28. Tonooka T, Sakata S, Kitahara M, Hanai M, Ishizeki S, Takada M, et al. Detection and quantification of four species of the genus Clostridium in infant feces. Microbiol Immunol. 2005;49:987-92.

29. dela Cruz WP, Gozum MM, Lineberry SF, Stassen SD, Daughtry M, Stassen NA, et al. Rapid detection of enterotoxigenic Clostridium perfringens by real-time fluorescence resonance energy transfer PCR. J Food Prot. 2006:69:1347-53.

30. Loh JP, Liu YC, Chew SW, Ong ES, Fam JM, Ng YY, et al. The rapid identification of Clostridium perfringens as the possible aetiology of a diarrhoeal outbreak using PCR. Epidemiol Infect. 2008;136:1142-6.

31. Rinttila T, Lyra A, Krogius-Kurikka L, Palva A. Real-time PCR analysis of enteric pathogens from fecal samples of irritable bowel syndrome subjects. Gut Pathog. 2011;3:6-15.

32. Linhai L, Yuling S, Lidan C, Lanlan Z, Luxia W, Zhaohui S, et al. Effectiveness and clinical applications of real-time fluorescence-based quantitative PCR system for the detection of Clostridium perfringens. Afr J Microbiol Res. 2012;6:2828-34.

33. Kim S, Labbe RG, Ryu S. Inhibitory effects of collagen on the PCR for detection of Clostridium perfringens. Appl Environ Microbiol. 2000;66:1213-5.

34. Monteiro L, Gras N, Vidal R, Cabrita J, Megraud F. Detection of Helicobacter pylori DNA in human feces by PCR: DNA stability and removal of inhibitors. J Microbiol Methods. 2001;45:89-94.

35. Kubota H, Sakai T, Gawad A, Makino H, Akiyama T, Ishikawa E, et al. Development of TaqMan-based quantitative PCR for sensitive and selective detection of toxigenic Clostridium difficile in human stools. PLOS One. 2014:9:e111684

36. Thompson JD, Gibson TJ, Plewniak F, Jeanmougin F, Higgins DG. The CLUSTAL_X windows interface: flexible strategies for multiple sequence alignment aided by quality analysis tools. Nucleic Acids Res. 1997;25:4876-82.

37. Fukushima $H$, Tsunomori $Y$, Seki R. Duplex real-time SYBR green $P C R$ assays for detection of 17 species of food- or water-borne pathogens in stools. J Clin Microbiol. 2003:41:5134-46.

38. Matsuda K, Tsuji H, Asahara T, Matsumoto K, Takada T, Nomoto K. Establishment of an analytical system for the human fecal microbiota, based on reverse transcription-quantitative PCR targeting of multicopy rRNA molecules. Appl Environ Microbiol. 2009;75:1961-9.

39. Jansen GJ, Wildeboer-Veloo AC, Tonk RH, Franks AH, Welling GW. Development and validation of an automated, microscopy-based method for enumeration of groups of intestinal bacteria. J Microbiol Methods. 1999;37:215-21.

40. Matsuki T, Watanabe K, Fujimoto J, Kado Y, Takada T, Matsumoto K, et al. Quantitative PCR with $16 \mathrm{~S}$ rRNA-gene-targeted species-specific primers for analysis of human intestinal bifidobacteria. Appl Environ Microbiol. 2004;70:167-73.

41. Bustin SA, Benes V, Garson JA, Hellemans J, Huggett J, Kubista M, et al. The MIQE guidelines: minimum information for publication of quantitative real-time PCR experiments. Clin Chem. 2009;55:611-22.

42. Billington SJ, Wieckowski EU, Sarker MR, Bueschel D, Songer JG, McClane BA. Clostridium perfringens type $\mathrm{E}$ animal enteritis isolates with highly conserved, silent enterotoxin gene sequences. Infect Immun. 1998;66:4531-6. 
43. Matsuda K, Tsuji H, Asahara T, Takahashi T, Kubota H, Nagata S, et al. Sensitive quantification of Clostridium difficile cells by reverse transcriptasequantitative PCR targeting rRNA molecules. Appl Environ Microbiol. 2012;78:5111-8.

44. Sutton RGA. Enumeration of Clostridium welchii in the feces of varying sections of the human population. J Hyg. 1966;64:367-74

45. Yamagishi T, Serikawa T, Morita R, Nakamura S, Nishida S. Persistent high numbers of Clostridium perfringens in the intestines of Japanese aged adults. Jpn J Microbiol. 1976;20:397-403.

46. Stringer MF, Watson GN, Gilbert RJ, Wallace JG, Hassall JE, Tanner El, et al. Faecal carriage of Clostridium perfringens. J Hyg (Lond). 1985;95:277-88.

47. Samuel SC, Hancock P, Leigh DA. An investigation into Clostridium perfringens enterotoxin associated diarrhoea. J Hosp Infect. 1991;18:219-30.

48. Uppalapati SR, Kingston JJ, Qureshi IA, Murali HS, Batra HV. In silico, in vitro and in vivo analysis of binding affinity between $\mathrm{N}$ and C-domains of Clostridium perfringens alpha toxin. PLoS One. 2013:8:e82024.

49. Wu J, Zhang W, Xie B, Wu M, Tong X, Kalpoe J, et al. Detection and toxin typing of Clostridium perfringens in formalin-fixed, paraffin-embedded tissue samples by PCR. J Clin Microbiol. 2009:47:807-10.

50. Sparks SG, Carman RJ, Sarker MR, McClane BA. Genotyping of enterotoxigenic Clostridium perfringens isolates associated with gastrointestinal disease in North America. J Clin Microbiol. 2001;39:883-8.

51. Forward LJ, Tompkins DS, Brett MM. Detection of Clostridium difficile cytotoxin and Clostridium perfringens enterotoxin in cases of diarrhea in the community. J Med Microbiol. 2003;52:753-7.

52. Heikinheimo $A$, Lindstrom $M$, Granum PE, Korkeala $H$. Humans as reservoir for enterotoxin gene-carrying Clostridium perfringens type A. Emerg Infect Dis. 2006;12:1724-9.

53. Tanaka D, Kimata K, Shimizu M, Isobe J, Watahiki M, Karasawa T, et al Genotyping of Clostridium perfringens isolates collected from food poisoning outbreaks and healthy individuals in Japan based on the cpe locus. Jpn J Infect Dis. 2007;60:68-9.

54. Li J, Sayeed S, McClane BA. Prevalence of enterotoxigenic Clostridium perfringens isolates in Pittsburgh (Pennsylvania) area soil and home kitchens. Appl Environ Microbiol. 2007;73:7218-24.

55. Miki Y, Miyamoto K, Kaneko-Hirano I, Fujiuchi K, Akimoto S. Prevalence and characterization of enterotoxin gene carrying Clostridium perfringens isolates from retail meat products in Japan. Appl Environ Microbiol. 2008:74:5366-72.

56. Brook I. Clostridial infection in children. J Med Microbiol. 1995;42:78-82.

57. de la Cochetiere MF, Piloquet H, des Robert C, Darmaun D, Galmiche JP, Roze JC. Early intestinal bacterial colonization and necrotizing enterocolitis in premature infants: the putative role of Clostridium. Pediatr Res. 2004:56:366-70.

58. Yap GC, Loo EX, Aw M, Lu Q, Shek LP, Lee BW. Molecular analysis of infant fecal microbiota in an Asian at-risk cohort-correlates with infant and childhood eczema. BMC Res Notes. 2014;7:166. doi:10.1186/1756-0500-7-166.

59. Mevissen-Verhage EA, Marcelis JH, de Vos MN, Harmsen-van Amerongen WC, Verhoef J. Bifidobacterium, Bacteroides, and Clostridium spp. in fecal samples from breast-fed and bottle-fed infants with and without iron supplement. J Clin Microbiol. 1987;25:285-9.

60. Tsuji H, Oozeer R, Matsuda K, Matsuki T, Ohta T, Nomoto K, et al. Molecular monitoring of the development of intestinal microbiota in Japanese infants. Benef Microbes. 2012;3:113-25.

61. Hopkins MJ, Sharp R, Macfarlane GT. Variation in human intestinal microbiota with age. Dig Liver Dis. 2002;34:S12-8.

62. Macfarlane GT, Macfarlane LE. Acquisition, evolution and maintenance of the normal gut microbiota. Dig Dis. 2009;27:90-8.

63. Enck P, Zimmermann K, Rusch K, Schwiertz A, Klosterhalfen S, Frick JS. The effects of ageing on the colonic bacterial microflora in adults. Z Gastroenterol. 2009;47:653-8.

64. Putignani L, Del Chierico F, Petrucca A, Vernocchi P, Dallapiccola B. The human gut microbiota: a dynamic interplay with the host from birth to senescence settled during childhood. Pediatr Res. 2014;76:2-10.

65. Bergstrom A, Skov TH, Bahl MI, Roager HM, Christensen LB, Ejlerskov KT, et al. Establishment of intestinal microbiota during early life: a longitudinal, explorative study of a large cohort of Danish infants. Appl Environ Microbiol. 2014:80:2889-900.
66. Benno Y, Endo K, Mizutani T, Namba Y, Komori T, Mitsuoka T. Comparison of fecal microflora of elderly persons in rural and urban areas of Japan. Appl Environ Microbiol. 1989;55:1100-5.

67. Smith JL. Foodborne illness in the elderly. J Food Prot. 1998;61:1229-39.

68. McClane BA. Clostridium perfringens. In: Doyle MP, Beuchat LR, Montville TJ, editors. Food Microbiology: Fundamentals and Frontier. Washington DC: ASM Press; 2001. p. 351-72.

69. Fukushima H, Katsube K, Hata Y, Kishi R, Fujiwara S. Rapid separation and concentration of food-borne pathogens in food samples prior to quantification by viable-cell counting and real-time PCR. Appl Environ Microbiol. 2007;73:92-100.

70. Jung-Whan C, Park JS, Hyeon JY, Park C, Song KY, Hong KW, et al. Development of real-time PCR for the detection of Clostridium perfringens in meats and vegetables. J Microbiol Biotechnol. 2012;22:530-4.

71. Kanakaraj R, Harris DL, Songer JG, Bosworth B. Multiplex PCR assay for detection of Clostridium perfringens in feces and intestinal contents of pigs and swine feed. Vet Microbiol. 1998;63:29-38.

72. Wise MG, Siragusa GR. Quantitative detection of Clostridium perfringens in the broiler fowl gastrointestinal tract by real-time PCR. Appl Environ Microbiol. 2005;71:3911-6.

73. Gurjar AA, Hegde NV, Love BC, Jayarao BM. Real-time multiplex PCR assay for rapid detection and toxintyping of Clostridium perfringens toxin producing strains in feces of dairy cattle. Mol Cell Probes. 2008;22:90-5.

74. Kikuchi E, Miyamoto Y, Narushima S, Itoh K. Design of species-specific primers to identify 13 species of Clostridium harbored in human intestinal tracts. Microbiol Immunol. 2002;46:353-8.

\section{Submit your next manuscript to BioMed Central and take full advantage of:}

- Convenient online submission

- Thorough peer review

- No space constraints or color figure charges

- Immediate publication on acceptance

- Inclusion in PubMed, CAS, Scopus and Google Scholar

- Research which is freely available for redistribution 